\title{
Status and Trends of Sediment Metal Pollution in Bohai Sea, China
}

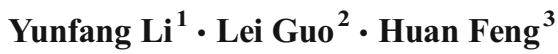

Published online: 7 November 2015

(C) Springer International Publishing AG 2015

\begin{abstract}
This paper summarizes the advancement in the Bohai Sea sediment metal pollution studies in China. It includes spatial metal distributions, anthropogenic sources, and pollutant transport as well as factors affecting concentrations and potential ecological risk due to metal contamination. The results indicate that the pollution in the Bohai Sea is serious in coastal areas and, if no protection procedures are implemented, the situation can become worse with the economic development in the Bohai Sea rim. It is found that the metal distributions are quite different due to different pollutant sources in the coastal areas as well as along-shore current transport. The study shows that metal pollution is the most serious in the northern Liaodong Bay, followed by Bohai Bay and Laizhou Bay. The pollution in these three bays is much more serious than that in the central basin of the Bohai $\mathrm{Sea} . \mathrm{Hg}, \mathrm{Cd}$, and $\mathrm{Pb}$ are the predominant pollutants commonly found in the Bohai Sea although the degree of the pollution varies with different regions of the Bohai Sea. Finally, the paper points out the current environmental concerns with the Bohai Sea sediment metal pollution.
\end{abstract}

This article is part of the Topical Collection on Sediment and Other Pollutions

Yunfang Li

sdzyfl@163.com

1 School of Science, Qingdao Technological University, Qingdao, Shandong 266033, People's Republic of China

2 Guangdong Research Institute of water resources and Hydropower, Guangzhou, Guangdong 510610, People's Republic of China

3 Department of Earth and Environmental Studies, Montclair State University, Montclair, NJ 07043, USA
Keywords China $\cdot$ Bohai Sea $\cdot$ Sediment $\cdot$ Heavy metal . Pollution

\section{Introduction}

The Bohai Sea in China is a semi-enclosed inland sea, including three bays (i.e., Liaodong Bay in the north, Bohai Bay in the west, and Laizhou Bay in the south) and a central basin and is connected with the Yellow Sea via the Bohai strait in the east (Fig. 1). It covers an area of $1.60 \times 10^{4} \mathrm{~km}^{2}$ with a population of about 70 million living in its coastal area. The average water depth in the Bohai Sea is $12.5 \mathrm{~m}$ with a maximum depth of $32 \mathrm{~m}[1,2]$. Both water exchange capacity and selfpurification ability are poor in the Bohai Sea. With the rapid social and economic development around the Bohai Sea rim, discharge of heavy metal pollutants into the Bohai Sea is increasing, which has rapidly worsened the Bohai Sea environmental quality [3]. Yellow River, Haihe River, Liaohe River, and Luanhe River also discharge into the Bohai Sea, carrying different materials from different land-based sources. It is reported that rivers and streams around the Bohai Sea are the main source input of heavy metals [4].

Before the early 1990s, there were very few sediment studies in the Bohai Sea. Investigations were limited to some estuaries and harbors [5, 6-8] until August-October 1998 when the National Oceanic Administration of China organized the second campaign of sediment pollution investigation in all China seas. The survey parameters included heavy metals (such as $\mathrm{Hg}, \mathrm{Cd}, \mathrm{Pb}$, and $\mathrm{Cs}$ ), total nitrogen and phosphorus, organic matters, sulfide, and organic pollutants (such as DDTs, PCBs, PAHs, and phthalate). This investigation provided a reference for study of sediment pollutant distributions, sources, transport, chemical speciation, and sedimentation in the Bohai Sea $[9,10]$. The results of the survey showed that 


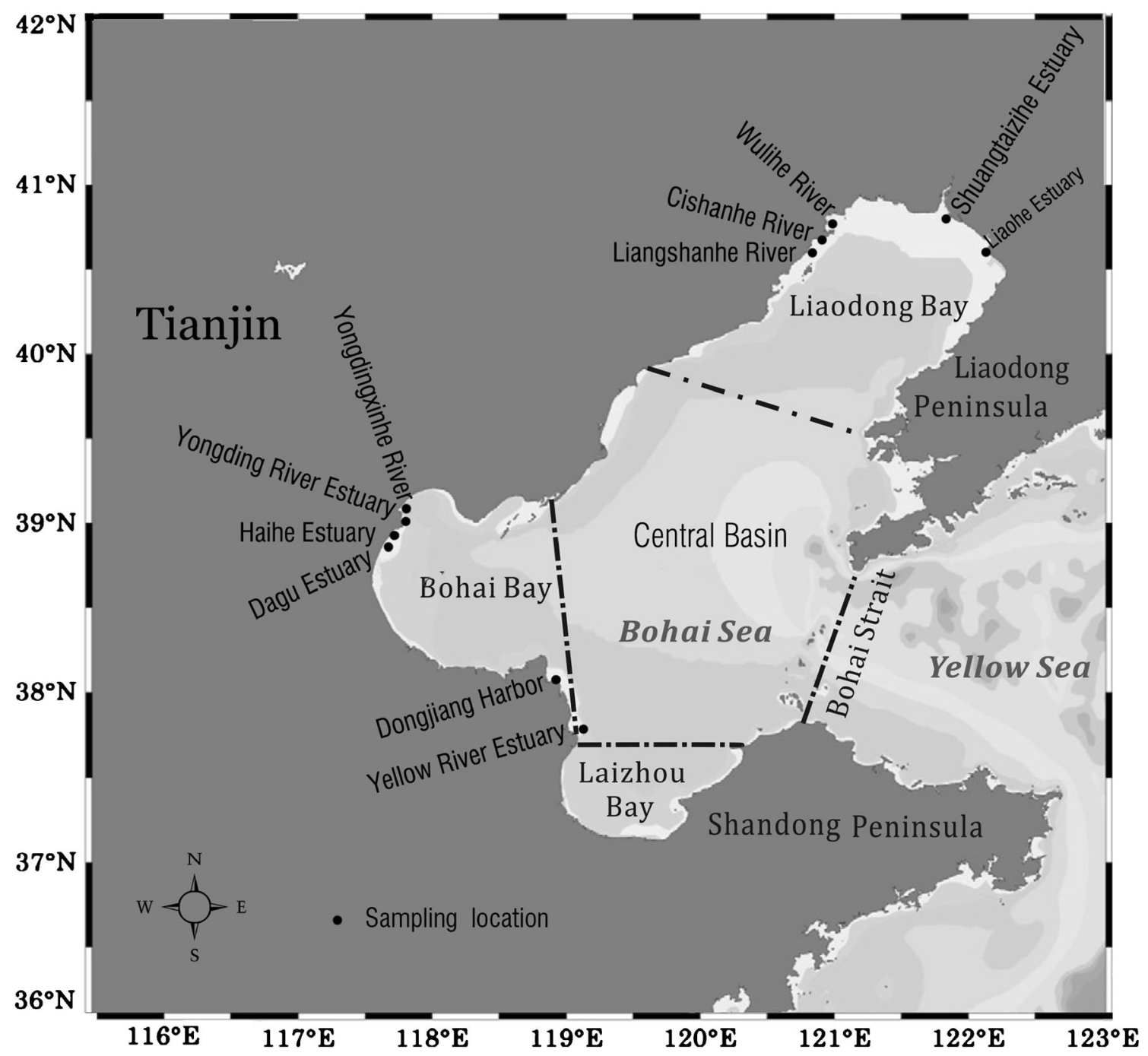

Fig. 1 Map of the Bohai Sea, China

the pollution in The Bohai Sea was very serious and became worse. In December 1998, the Bohai Blue Sea Plan [11] was officially launched with a focus on the comprehensive control of some key areas, estuaries, and pollutants. Since then, studies have been paying more attention to sediment pollution in the Bohai Sea.

Many studies have indicated that the interaction among heavy metals, biological macro-molecules group, and genetic materials may cause deformity, mutation, and cancer [12-14]. Most of the heavy metals in water body are scavenged by suspended particles falling down to the sediments. However, metals adsorbed on the sediments can be released into the overlying water due to contaminated sediment resuspension under certain environmental conditions, e.g., current and wave activities. Furthermore, toxic metals can threaten the ecological system directly and indirectly due to biological accumulation and magnification [15]. Therefore, heavy metal pollution research is very critical in order to protect the ecological system. In the past two decades, environmental scientists have conducted numerous heavy metal pollution studies in the Bohai Sea, including characterization of heavy metal sources, transport, and distributions, as well as the controlling factors by tracking the pollution history in this area $[16,17]$.

\section{Characterization of Sediment Metal Concentrations and Spatial Distributions}

The ${ }^{210} \mathrm{~Pb}$ radioisotope dating technique is useful to study the history of metal (e.g., $\mathrm{Cu}, \mathrm{Pb}, \mathrm{Zn}$, and $\mathrm{Cd}$ ) concentrations and distributions in the Bohai Sea sediments [6, 18-20] because the concentrations and spatial distributions of heavy metals in the sediments are important indicators of the aquatic environment $[21,22]$. The results of some heavy metal concentrations in the Bohai Sea sediments from the selected studies are summarized in Table 1. As shown in Table 1, the heavy metal 


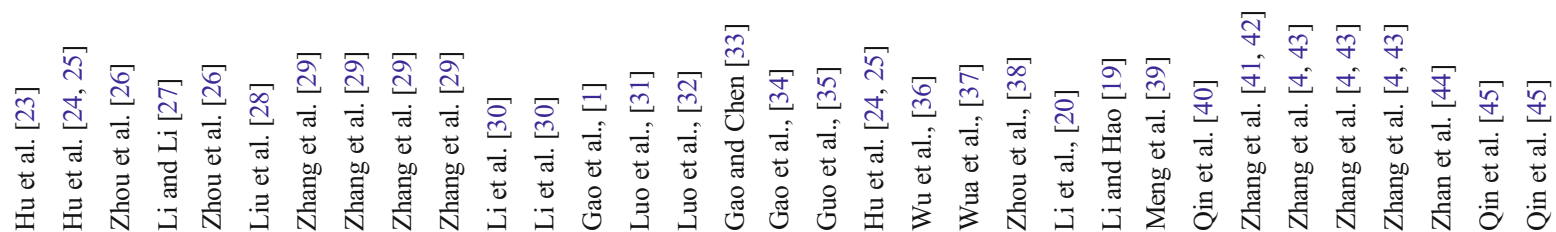

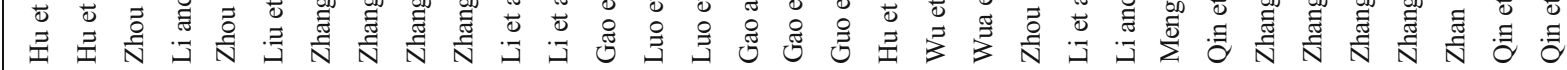

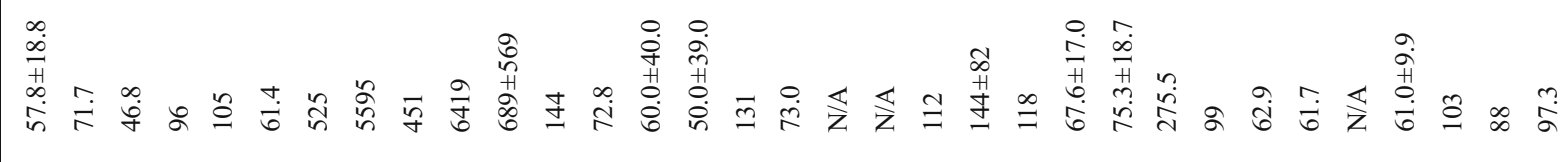

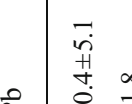

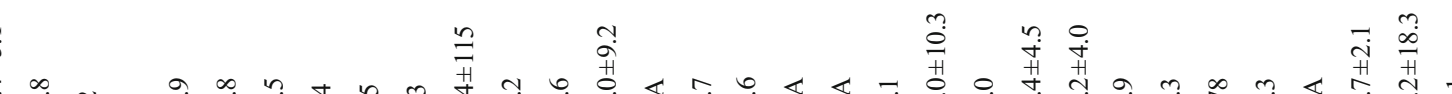
苛

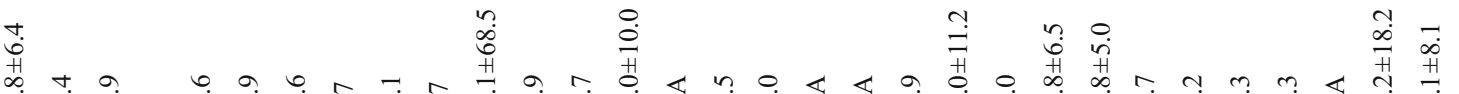

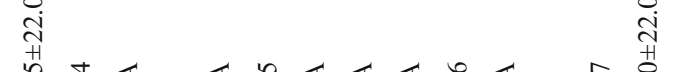

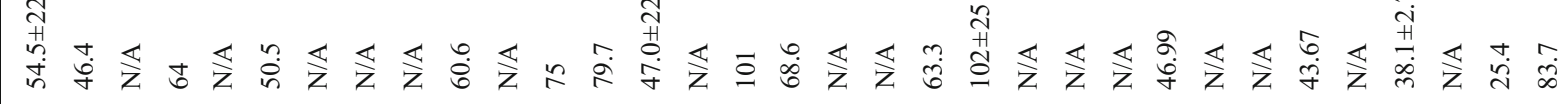

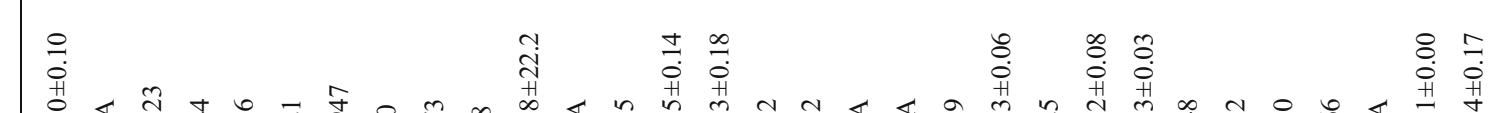

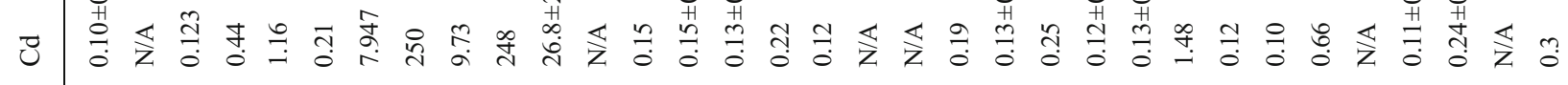

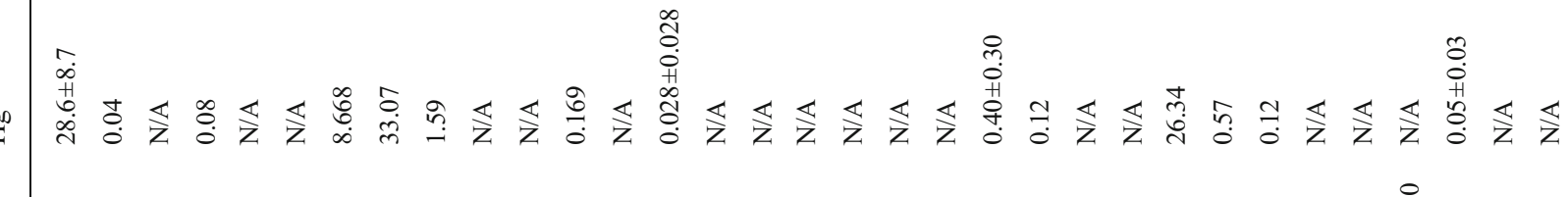

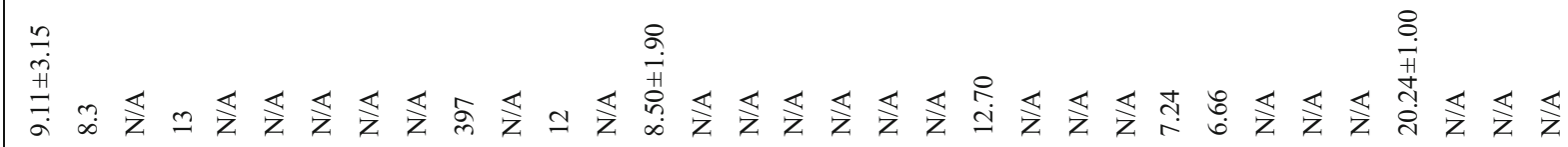
(1)

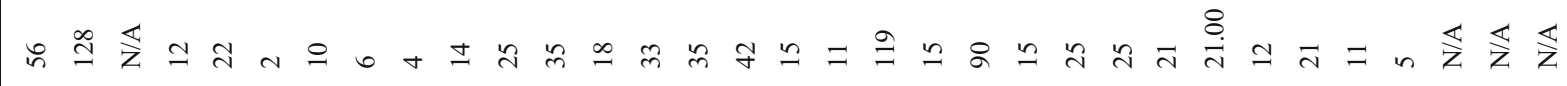

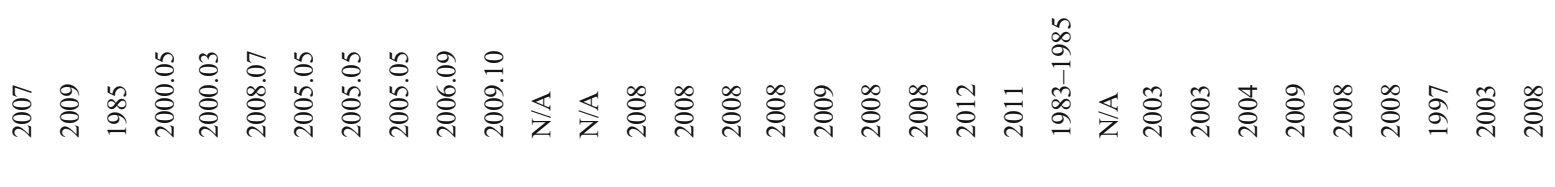

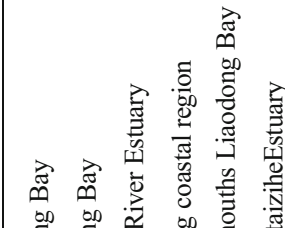<smiles>[CH][CH][CH]</smiles>

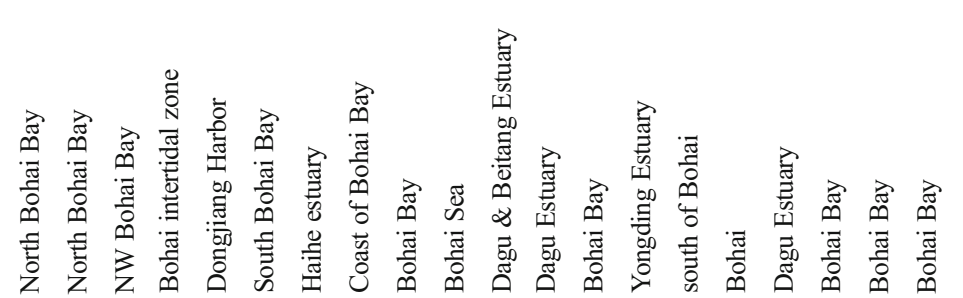




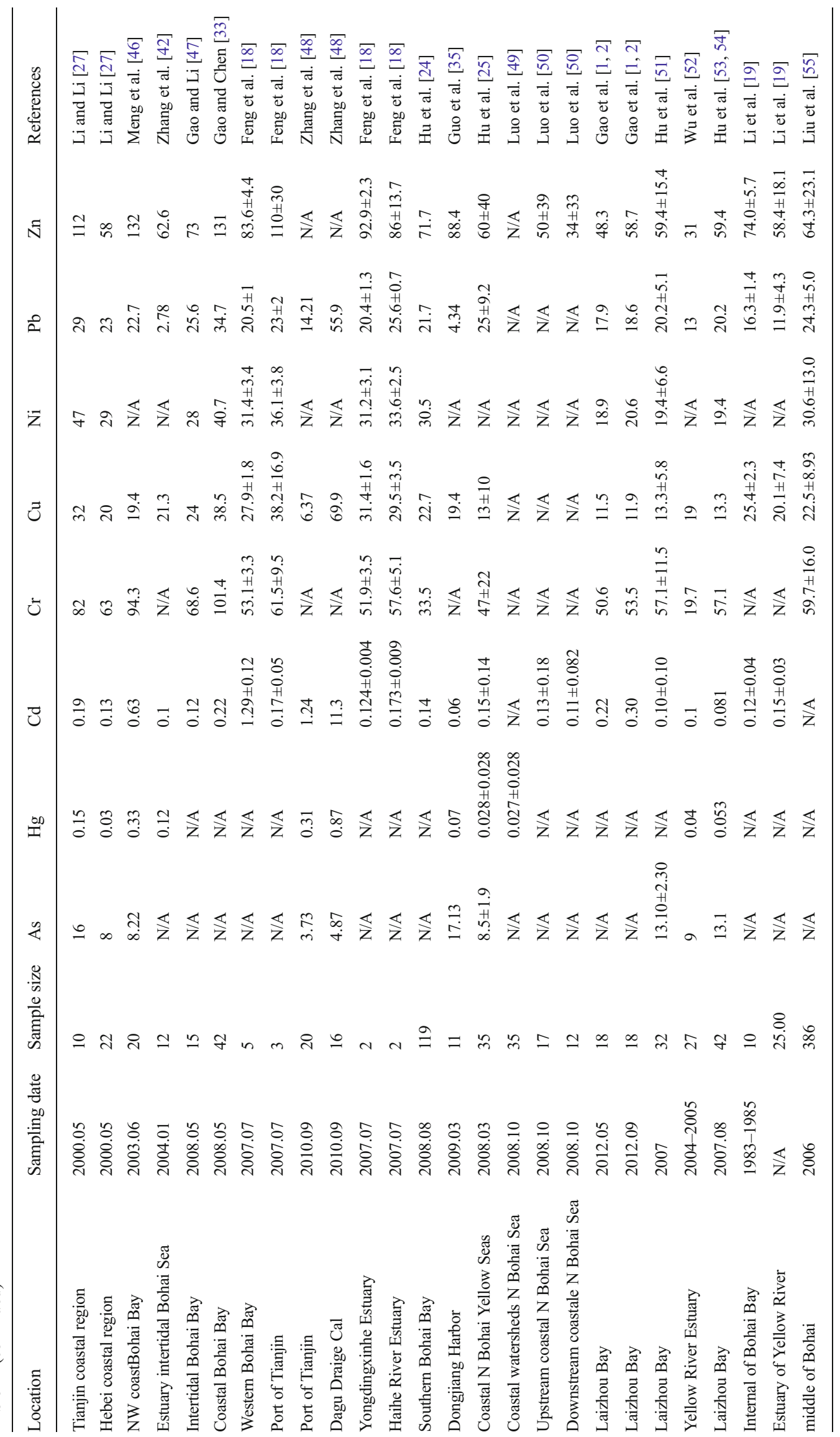


concentrations are different from area to area because of different local pollutant sources along the coast. For example, the concentrations of $\mathrm{Hg}, \mathrm{Cd}$, and $\mathrm{As}$ in the coast of Tianjin and Liaoning were much higher than that in Yellow River Delta [27, 45, 56-58], which could be attributed to industrial waste and sewage discharging through Haihe River and Liaohe Reiver in Tianjing and Liaoning area. The concentrations of $\mathrm{Hg}, \mathrm{Cd}$, and $\mathrm{Zn}$ in some areas in the Bohai Sea were 12 to 150 times higher than the background concentrations. The pollution was mainly caused by rapid economic development in the areas around the Bohai Sea [18]. The studies on sediment metal pollution in the intertidal zone of the Bohai Sea showed that heavy metal (As, $\mathrm{Cd} \mathrm{Cr}, \mathrm{Cu}, \mathrm{Pb}$, and $\mathrm{Zn}$ ) concentrations were the highest in Liaodong Bay, followed by Bohai Bay (ranked as the second highest) and Laizhou Bay (ranked as the third highest) $[4,43]$. The correlation analysis suggested that $\mathrm{Cr}, \mathrm{Cu}, \mathrm{Zn}$, $\mathrm{Cd}$, and $\mathrm{Pb}$ may have similar sources, but the major sources of As may be different from other metals [4, 43]. Studies also showed that sediment heavy metal concentrations, especially $\mathrm{Pb}$ and $\mathrm{Hg}$, were increasing in many estuaries around the Bohai Sea [59].

Besides the large scale studies conducted in the entire Bohai Sea, there were many intensive regional studies conducted in many localized areas in the Bohai Sea to obtain important local information. For example, spatial analysis of metal concentrations in the west Bohai Sea indicates that heavy metal concentrations decreased from near-shore to off-shore and from south to north [60]. The concentrations of $\mathrm{Cr}, \mathrm{Zn}, \mathrm{Cu}, \mathrm{Pb}$, and $\mathrm{Cd}$ were higher in estuaries and in the middle section of Tianjin coastal area [61]. Due to the different contaminant sources along the coastal area, the vertical profiles of heavy metal concentrations showed wavy distributions [62]. The metal enrichment in the sediments was obviously caused by human activities (Gao et al., 2012 [45, 58]). High levels of $\mathrm{Pb}$ and $\mathrm{Zn}$ appeared especially in the estuaries, indicating that river discharge was the main pollution source [46]. In Dagukou of Haihe River estuary, $\mathrm{Cu}, \mathrm{As}, \mathrm{Pb}$, and $\mathrm{Cd}$ were major contaminants in the sediments. The results indicate that the sediments in the estuary or nearshore were easily affected by land-based pollutant input [4, 43]. Two minimum heavy metal concentrations were found in a core collected from the Haihe River estuary. According to age determination, these two minimum concentrations respond to the time periods of 1938-1942 and 1960-1967 when the flooding events occurred in the northern part of Haihe River water system in 1939 and 1963, respectively [63]. In the intertidal zone of Yongding River estuary, it was found that the sediment mental concentrations changed with tides - the concentrations of $\mathrm{Cu}, \mathrm{Pb}$, and $\mathrm{Hg}$ were higher in spring tidal period but $\mathrm{Zn}$ and $\mathrm{Cd}$ were higher in neap tidal period because of the different sources. However, the vertical profiles of the heavy metal concentrations were always higher in the upper section of sediments than that in the lower section no matter in spring or neap tidal period [42]. The results suggest high metal input in recent years possibly due to urbanization and economic development in the area in last two decades [18].

In the north of the Bohai Sea, the distributions of sediment heavy metals in Liaodong Bay were controlled by four different factors, i.e., the particle size, concentration of organic materials, distance from estuaries, and ocean currents [23]. The concentrations of $\mathrm{Hg}, \mathrm{Cd}$, and $\mathrm{Pb}$ were higher near Qinhuang Island and argillaceous zone in Liaodong Bay. The concentrations of $\mathrm{As}, \mathrm{Hg}, \mathrm{Pb}$, and $\mathrm{Cd}$ as well as $\mathrm{Hg}$ were particularly high in the marginal area of the Luanhe River Delta. The concentrations of $\mathrm{Hg}, \mathrm{Pb}$, and $\mathrm{Cd}$ were also high near Liaodong Peninsula in Liaodong Bay [23]. It was found that the concentrations of $\mathrm{Zn}, \mathrm{Pb}$, $\mathrm{Cd}$, and $\mathrm{Hg}$ increased abruptly after 1970s. Coincident to the increase of heavy metal contents, the decreasing trend of ${ }^{206} \mathrm{~Pb}$ to ${ }^{207} \mathrm{~Pb}$ ratio indicated that $\mathrm{Pb}$ in the surface sediments mainly came from the anthropogenic activities [64, 65]. As shown in Table 1, the China State Bureau of Quality and Technical Supervision (CSBTS) [66] enacted Marine Sediment Quality (GB 18668-2002) to prevent and control marine pollution, protect marine life, ensure marine resource sustainable uses, maintain marine ecological equilibrium, and protect human health. The first level of sediment standard criteria is the most conservative with respect to metal toxicity and is used to protect marine life. The second level standards are also developed to regulate general industrial uses and protect coastal tourism. The third level standards are developed to address the management of harbors and special uses for ocean exploration. According to China National Standard for Marine Sediment Quality, the pollution of $\mathrm{Zn}, \mathrm{As}, \mathrm{Cd}$, and $\mathrm{Pb}$ in Jinzhou Bay was extremely serious and some areas in Jinzhou Bay had very high metal concentrations that can constituted a long-term ecological risk (Table 1, [29]).

In the southern portion of The Bohai Sea, the concentrations of $\mathrm{Cu}, \mathrm{Zn}, \mathrm{Pb}, \mathrm{Cd}, \mathrm{As}, \mathrm{Ni}$, and $\mathrm{Cr}$ in Laizhou Bay decreased from nearshore to bay and are higher in northern portion than those in the southern portion with high Ag in the central circulation area that was located in southwest central Laizhou Bay. The ecological risk caused by As and $\mathrm{Ni}$ was most serious in northwest section of Yellow River estuary, followed by the center and north of Laizhou Bay [51]. In costal Laizhou Bay, the results showed that the $\mathrm{Cr}$, $\mathrm{Cu}, \mathrm{Ni}$, and $\mathrm{Zn}$ were the main environmental threat according to the sediment quality guidelines. The marine area was generally in good condition with low risk from heavy metals and adverse effects on biota could hardly occur. Natural sources dominated the concentrations and distribution of $\mathrm{Cu}, \mathrm{Ni}, \mathrm{Pb}$, and $\mathrm{Zn}$ [57]. In the intertidal Bohai Bay, the studies indicated 
that sediment grain size played an important role in controlling metal concentrations [34].

\section{Source and Transport of Heavy Metals}

The vertical distributions of heavy metals in the sediments kept the historic record of heavy metal contamination in water and can provide the information of heavy metal source changes and evolution processes [67]. Radioisotope dating of sediments is the key step to study sources of pollutants. Environmental geochemists often make use of ${ }^{210} \mathrm{~Pb}$ method (e.g., [68]). Qi et al. [69] analyze the radioactivity of ${ }^{210} \mathrm{~Pb}$ in the Bohai Sea and the Yellow Sea for sedimentation study. Li et al. [20] estimated the sediment deposition rate in the Bohai Sea and found that it was rapid in estuary as well as nearby areas but slow in the central basin of the Bohai Sea. Meng et al. [70] measured ${ }^{210} \mathrm{~Pb}$ and ${ }^{137} \mathrm{Cs}$ spatial and temporal distribution patterns to investigate the sediment transport in western Bohai Bay. These studies indicated that sandy areas of the intertidal zone experienced rapid sedimentation from the 1950s to 1960s due to the fact that Northern China had plentiful precipitation during that time period. The sedimentation rate decreased after the 1960 s because of the reduction of sand transported to the intertidal zone as a consequence of diminished rainfall in Northern China and intensive human activities in the Haihe basin. The sedimentation rate generally increased from north to south. Feng et al. [71] study the temporal and spatial variations of ${ }^{210} \mathrm{~Pb}$ and ${ }^{7} \mathrm{Be}$ in western Bohai Sea and found that it was a non-steady state depositional environment. By comparing ${ }^{210} \mathrm{~Pb}$ and ${ }^{7} \mathrm{Be}$ inventories in sediments with those from atmosphere source input, they found that the sediments dredged from Tianjin Harbor or eroded from estuarine, and coastal areas were retained for a relatively short time (several months), as reflected in the relatively high ${ }^{7} \mathrm{Be}$ inventory despite local variability in sediment dynamic and disturbance due to human activities. However, ${ }^{210} \mathrm{~Pb}$ inventories in sediments indicated that there was a net on-shore transport of sediments and, nevertheless, the sediments were massbalanced over a long-term (years to decades). $\mathrm{Hu}$ and his coworker [53, 54] studied ${ }^{210} \mathrm{~Pb}$ sedimentation rate and its relationship with sediments transport. The results showed that high sedimentation rates were in estuaries around the Bohai Sea with the highest rate in the Yellow River Delta, whereas the offshore area was characterized by low sedimentation rates. In the northern Shangdong Peninsula, iso-lines of sedimentation rates extended northeastward and decreased step wise with the lowest at eastern Chengshantou. Based on the distribution pattern of ${ }^{210} \mathrm{~Pb}$ and the sedimentation rates in southern Bohai Sea, most of the sediments from the Yellow River were deposited within the coastal area. There were small portions of those sediments which were transported along northern Shangdong Peninsula and through the Bohai Straits into northern Yellow Sea.

\section{Metal Pollution Assessment}

Correlation analysis is a statistical approach to study the interrelationship between variables. Many researchers judge the sources of pollutants by use of heavy metal correlations with a special element named as the reference element [72, 73]. Many investigators often use $\mathrm{Al}$ as the reference element because it is one of the most abundant elements on the earth and cannot be easily contaminated [74-78]. There means no anthropogenic contamination if the metal has a correlation with Al closed to the earth abundance ratio. In fact, the heavy metals in sediments always add up together and the concentrations of heavy metals decrease when the particle size increases. The statistical approaches mentioned above cannot eliminate the effect of particle size and natural source variations in heavy metal concentrations at the same time [79, 80]. In order to distinguish the natural sources from the anthropogenic sources, investigators usually normalize the metals of interest against the reference element to reduce the interference of particle size on heavy metal concentrations [81-84]. Liu et al. [55] analyzed the sources of sediment heavy metals in the central basin of the Bohai Sea by the use of Al as the reference element. The results indicated that the heavy metals were mainly from natural sources, but were impacted by human activities significantly. Qin et al. [45, 58] studied the sediment heavy metal sources in Tianjin section of Bohai Bay and found that the concentrations of $\mathrm{Pb}, \mathrm{Zn}$, and $\mathrm{Cd}$ were much higher than the background concentrations after the normalization, indicating obvious contamination by anthropogenic sources. In order to reach more reliable conclusions, several studies used integrated approaches to evaluate metal contamination. Meng et al. [39] studied heavy metals in sediment the intertidal zone of Bohai Bay by integrating correlation analysis with principal component analysis. They normalized metal contaminants using $\mathrm{Li}$ and $\mathrm{Sc}$ as the reference elements in order to validate the conclusions from the analysis of metal vertical distribution profile. The results suggested that $\mathrm{As}, \mathrm{Cd}, \mathrm{Cr}, \mathrm{Hg}, \mathrm{Pb}$, and $\mathrm{Zn}$ were mainly from anthropogenic sources, while $\mathrm{Cu}, \mathrm{Al}, \mathrm{Fe}$, and Ni were from natural sources. The metal enrichment factor approach was originally recommended by Kemp who proposed to use $\mathrm{Al}$ as a reference element. In principle, the higher the metal enrichment factor is, the worse the metal pollution is. $\mathrm{Hu}$ et al. $[23,51]$ combined enrichment factor approaches with principal component analysis to study the sources of heavy metals in Liaodong Bay and Laizhou Bay sediments. The results suggested that in Liaodong Bay Fe, Ti, Cu, Zn, Cr, $\mathrm{Ni}, \mathrm{Co}, \mathrm{Mn}$, and Sc were mainly originated from terrestrial 
sources (rock and soil), while $\mathrm{Ag}, \mathrm{As}, \mathrm{Cd}, \mathrm{Hg}$, and $\mathrm{Pb}$ were mainly from anthropogenic sources, and $\mathrm{Ba}$ and $\mathrm{Sr}$ from halobiosin sediments. In Laizhou Bay, $\mathrm{Fe}, \mathrm{Cu}, \mathrm{Cd}, \mathrm{Cr}, \mathrm{Ni}$, $\mathrm{Co}, \mathrm{Mn}$, and $\mathrm{V}$ are not enriched elements; As is the slight element; and $\mathrm{Pb}$ and $\mathrm{Ag}$ are moderate enriched elements [51]. Therefore, $\mathrm{Fe}, \mathrm{Cu}, \mathrm{Zn}, \mathrm{Cd}, \mathrm{Cr}, \mathrm{Ni}, \mathrm{Co}, \mathrm{Mn}, \mathrm{V}, \mathrm{As}$, and $\mathrm{Sc}$ in Laizhou Bay were mainly from natural sources, while $\mathrm{Ag}$ and $\mathrm{Pb}$ were mainly from anthropogenic sources. The conclusion was supported by another study [84] that $\mathrm{V}, \mathrm{Cr}$, $\mathrm{Co}, \mathrm{Ni}$, and $\mathrm{Cu}$ were not enriched in Bohai Bay, but $\mathrm{Pb}$ and $\mathrm{Cd}$ were slightly enriched. In Liaodong Bay, $\mathrm{Fe}, \mathrm{Ti}, \mathrm{Mn}, \mathrm{Cu}, \mathrm{Zn}$, $\mathrm{Ni}, \mathrm{Cr}, \mathrm{Co}, \mathrm{Sc}$, and $\mathrm{V}$ were nearly the same as the background concentrations, $\mathrm{As}$ is slightly enriched, and $\mathrm{Pb}, \mathrm{Cd}, \mathrm{Ag}$, and $\mathrm{Hg}$ were moderately enriched [23].

Another approach to evaluate sediment heavy metals pollution is potential ecological risk index [85], which is frequently used to evaluate the potential risk of heavy metal pollution in the sediments. It depends on the concentration of free metal ions and reflects not only pollution extent but also the potential risk degree of heavy metals. Previous studies indicate that the Bohai Bay has been slightly polluted by heavy metals, and the degree of heavy metal pollution from serious to minor is in the order of $\mathrm{Cd}, \mathrm{Hg}, \mathrm{Pb}, \mathrm{Cu}$, and $\mathrm{Zn}$ [86]. In Liaodong Bay wetland, the potential ecological risk is slightly higher than that in Dalinghe River and Liaohe River estuaries and much higher than that in Shuangtaizi River and Xiaolinghe River estuaries. The ecological risk caused by metal pollutants from high to low is in the order of $\mathrm{Cd}, \mathrm{Pb}$, $\mathrm{Cu}$, and $\mathrm{Zn}$ [26]. In Jinzhou Bay, $\mathrm{Zn}, \mathrm{As}, \mathrm{Cd}$, and $\mathrm{Pb}$ pollutions are extremely serious, which make Jiaozhou Bay in a high ecological risk for a long time [29]. In southern Bohai Sea, the potential ecological risk caused by the heavy metals from high to low is in the order of $\mathrm{Cd}, \mathrm{Pb}, \mathrm{Cu}, \mathrm{Cr}$, and $\mathrm{Zn}[4,43]$. In Tianjin section of Bohai Bay, the sediments quality is markedly polluted and $\mathrm{Hg}$ is the primary element of pollution which is seriously harmful to ecology [62]. Wang et al. [87] used the biological effect database to establish a heavy metal concentration standard for Jiaozhou Bay environmental quality control. By comprehensive use of sediment metal enrichment factor and Hakanson potential ecological risk index, several studies indicate that $\mathrm{Hg}$ and $\mathrm{Cd}$ are major ecological risk factors in southern Bohai Bay, and heavy metal pollution is more serious in the northern region than that in the southern region because of terrigenous input and coastal zone development in the northern region $[24,25,88]$.

Geo-accumulation index proposed by Professor Muller [89] is an important indicator to evaluate the environmental impact due to human activities because it takes the human activities into account. By the comprehensive use of the geo-accumulation index and potential ecological risk index, several studies found that $\mathrm{Cd}, \mathrm{Hg}$, and $\mathrm{Pb}$ were positively correlated in the Bohai Sea. Various levels of $\mathrm{Hg}$ pollution were found in different areas within the Bohai Sea, but $\mathrm{Cd}$ pollution was found the most serious in Liaodong Bay. $\mathrm{Hg}$ pollution was predominant near Qinhuang Island and, to a much less extent, in Laizhou Bay. Hg pollution was not found in Bohai Bay [77]. It was found that there was a slight metal pollution near Liaodong Peninsula, moderate metal pollution in Haihe River estuary, Tianjin coast and central Bohai Bay. The pollution was mainly caused by $\mathrm{Pb}$, followed by $\mathrm{Cr}, \mathrm{Zn}$, and V [55]. In the intertidal zone of the Bohai Sea, it was reported that $\mathrm{Cd}$ had caused moderate pollution and $\mathrm{Pb}$ had a slight impact. The ecological risk caused by heavy metal pollution from high to low was in the order of $\mathrm{Cd}, \mathrm{Pb}, \mathrm{As}, \mathrm{Cu}, \mathrm{Zn}$, and $\mathrm{Cr}$ in the intertidal zone $[4,43]$.

In ecological risk assessment, the approach using the potential ecological risk index is preferable for a large area because it eliminates the pollution influence by regional and sources differences [40]. In Laizhou Bay, the degree of metal pollution from high to low was reported in the order of $\mathrm{Cd}, \mathrm{Pb}$, $\mathrm{Zn}, \mathrm{Cu}, \mathrm{As}$, and $\mathrm{Hg}$. However, the potential ecological risk from high to low was reported in the order of $\mathrm{Hg}, \mathrm{Cd}, \mathrm{As}, \mathrm{Pb}$, $\mathrm{Cu}$, and $\mathrm{Zn},[1,2,34,90]$. The results show that there may be some deviations in the results obtained from the different approaches in sediment heavy metals pollution assessment. To access adverse biological effects on an ecological system, a variety of guidelines have been proposed to evaluate contaminant risks to organisms (e.g., [91-94]). Long et al. [93] established two frequently used metrics for evaluating potentially adverse effects of contaminants on ecosystems based on their "concentration effects" distributions. The lower 10th percentile of the effects data is the effects rangelow (ERL) concentration, while the median or 50th percentile of the effects data is referred to as the effects range-median (ERM) [93]. ERL and ERM values are usually combined to delineate three effects ranges, i.e., (1) at concentrations below the ERL, a minimal-effects range is anticipated, (2) at concentrations equal to or exceeding the ERL value but less than ERM, adverse effects might be expected to occasionally occur, and (3) at concentrations greater than or equivalent to the ERM, it is anticipated that adverse effects are likely to occur more than $50 \%$ of the time $[91,93,94]$. In this study, ERL and ERM criteria were used to compare observed metal concentrations to the likelihood of their causing adverse biological effects. The specific potential for toxicity was estimated by calculating the hazard quotients (HQs) of the selected chemical contaminants [95]:

$H Q=\frac{S C C}{S Q G}$

where SCC is the sediment chemical concentration in milligram per kilogram, and SQG is the sediment quality guideline in milligram per kilogram. SQG values were set at ERL levels: 

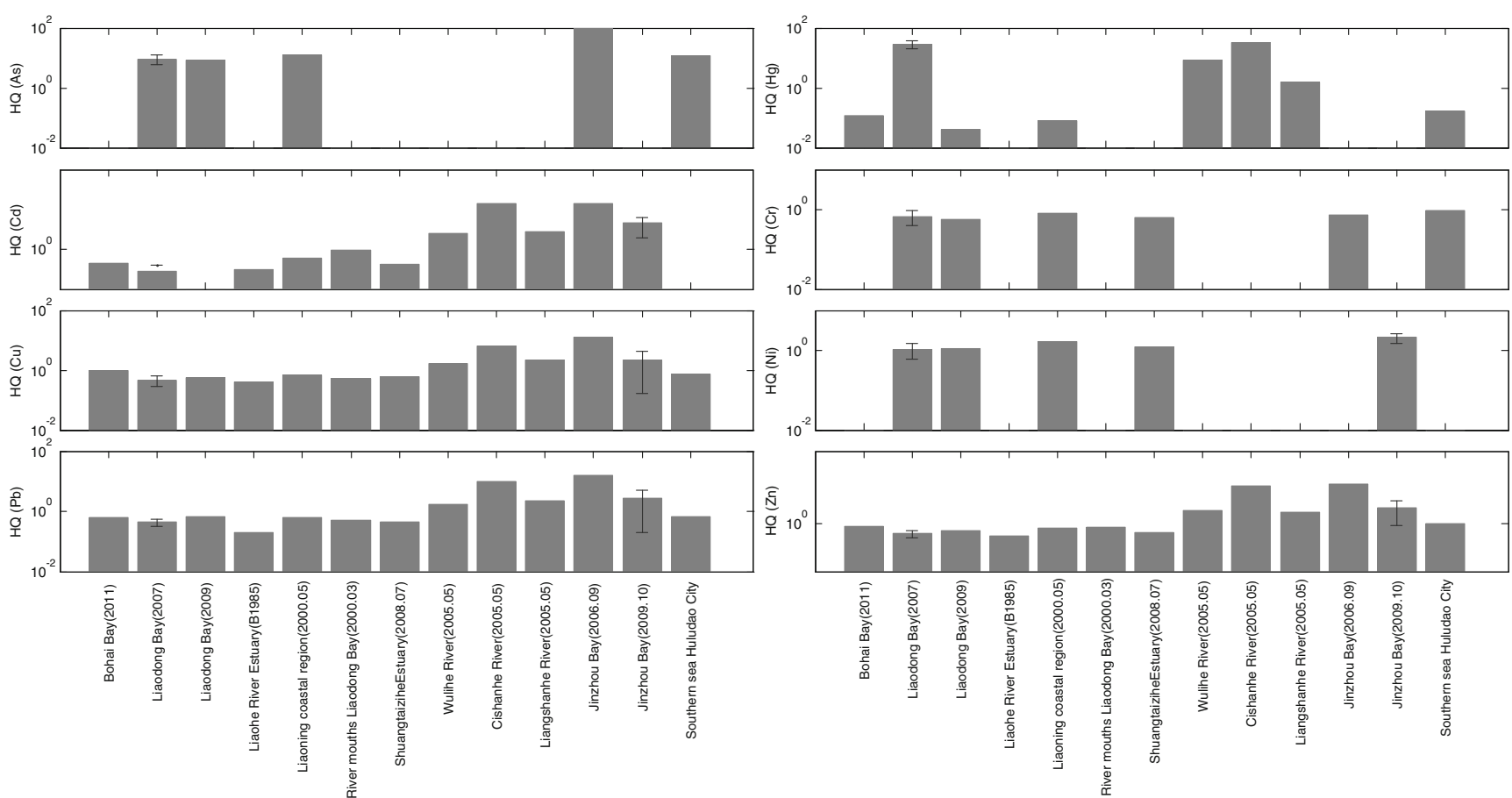

Fig. 2 Hazard Quotient of the Liaodong Bay, Bohai Sea, China

$\mathrm{Ag}=1.0, \mathrm{Cd}=1 \cdot 2, \mathrm{Cr}=81, \mathrm{Cu}=34, \mathrm{Ni}=20 \cdot 9, \mathrm{~Pb}=46 \cdot 7$, and $\mathrm{Zn}=150$ [93]. For toxicity characterization, HQ values were used to express the potential risk to ecological receptors: at $\mathrm{HQ}<0.1$ no adverse effects were expected; at $0.1<\mathrm{HQ}<1$ potential hazards were expected to be low, but in the range of $1.0<\mathrm{HQ}<10$, some adverse effects or moderate hazards are probable; and, finally, if $\mathrm{HQ}>10$, high hazard potential is anticipated [96, 97]. Coastal ecosystem is sensitive and vulnerable adverse biological effects. Hazard quotients of selected metals in Liaodong Bay system, Bohai Bay system, and Laozhou Bay system are summarized in Figs. 2, 3, and 4. Figure 2 shows metal HQ in Liaodong Bay and associated rivers and estuaries. In Liaodong Bay system, adverse biological effects caused by $\mathrm{As}$ and $\mathrm{Hg}$ in some
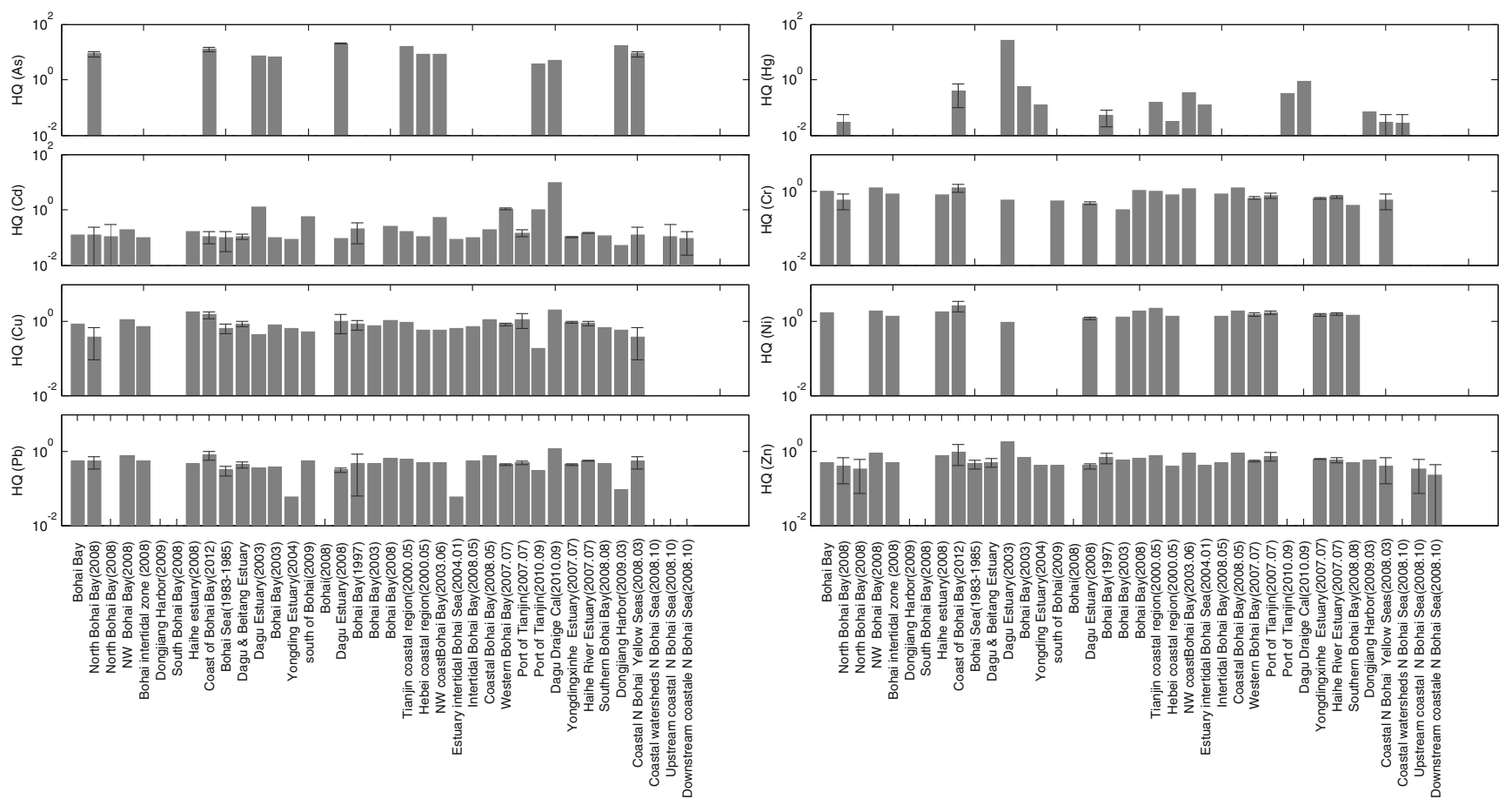

Fig. 3 Hazard Quotient of the Bohai Bay, Bohai Sea, China 


\section{Laizhou Bay}
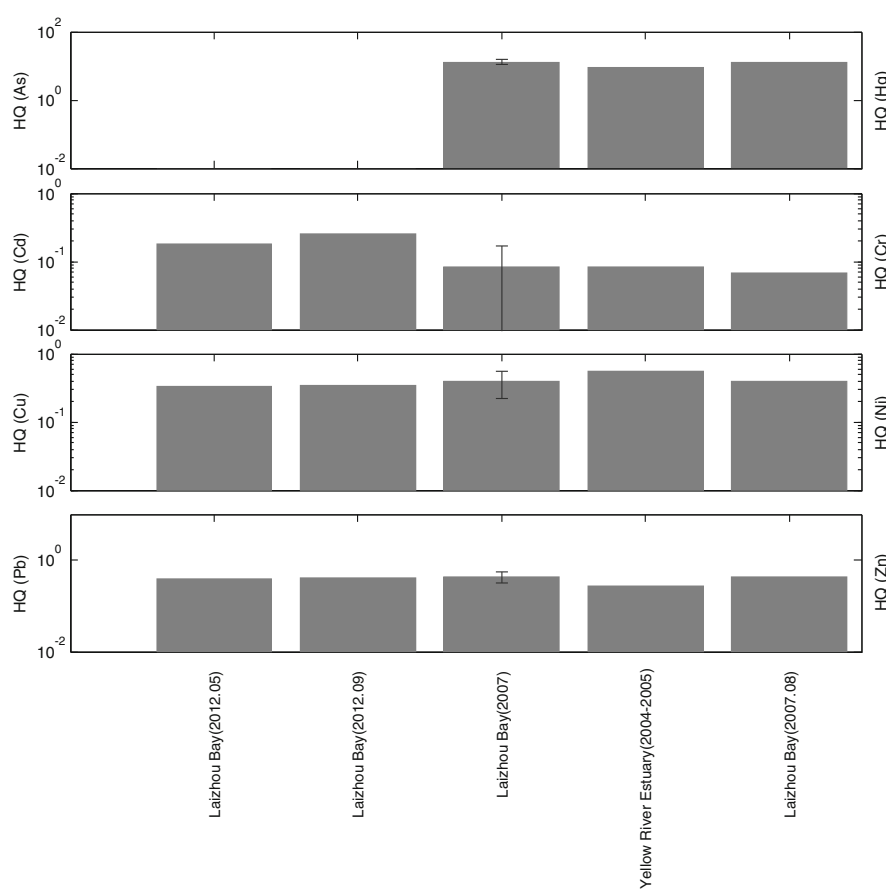

Fig. 4 Hazard Quotient of the Laizhou Bay, Bohai Sea, China

areas are expected as $\mathrm{HQ}>10$. The hazard potential caused by the other metals, such as $\mathrm{Cd}, \mathrm{Cr}, \mathrm{Cu}, \mathrm{Ni}, \mathrm{Pb}$, and $\mathrm{Zn}$, may be possible according to their HQ values $(1<\mathrm{HQ}<10)$ (Fig. 2). In Bohai Bay system, the situation is very similar to that in Liaodong Bay system. As and $\mathrm{Hg}$ have high hazard potential to cause adverse biological effect in some areas because of $\mathrm{HQ}>10$ (Fig. 3). Low to moderate hazards may be caused by $\mathrm{Cd}, \mathrm{Cr}, \mathrm{Cu}, \mathrm{Ni}, \mathrm{Pb}$, and $\mathrm{Zn}$ in some other areas $(1<\mathrm{HQ}<10)$ (Fig. 3). Laizhou Bay is in the southern portion of the Bohai Sea. There are limited data available for this system. As shown in Fig. 4, As is the only metal of concern, which has high hazard potential to cause adverse biological effects in Layzhou Bay and the Yellow River estuary. The adverse biological effects caused by $\mathrm{Hg}, \mathrm{Cd}$, $\mathrm{Cr}, \mathrm{Cu}, \mathrm{Ni}, \mathrm{Pb}$, and $\mathrm{Zn}$ in Laizhou Bay system are less concern according to their $\mathrm{HQ}$ values $(\mathrm{HQ}<1$ or $1<\mathrm{HQ}<$ 10) (Fig. 4). According to current analysis, the northern portion of the Bohai Sea including Liaodong Bay has high hazard potential that can cause adverse biological effects due to more severe metal pollution in the region.

\section{Current Concerns and Future Expectations in the Bohai Sea Environmental Research}

Current analysis of metal source input to the sediments may distinguish the natural sources from the anthropogenic sources. However, this is still at the qualitative analysis
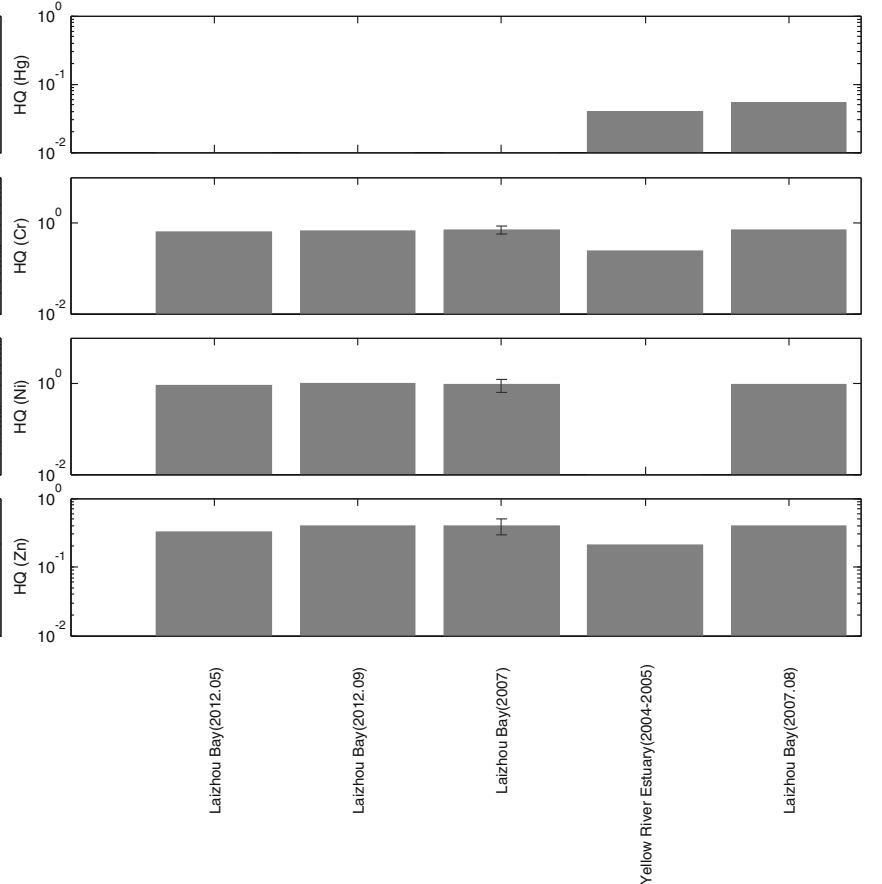

state without knowing the proportions from each source. A quantitative analysis of metal input from natural and anthropogenic sources is expected in the future. The secondary contamination is a serious environmental problem, but there is only a few studies on the metal releasing mechanisms and people still do not fully understand the processes [98]. It is necessary to take into account of each individual factor influencing the heavy metal release such as $\mathrm{Eh}, \mathrm{pH}$, organic materials, seasonal variations, temperature, water flow velocity, and wind-generated waves. Currently, there is no globally unified method for the data comparison especially in speciation analysis. Because of this fact, there exists deviation in evaluation of sediment heavy metal pollution because the results are obtained by different analytical methods and based on different assessment criteria. The unification of analytical methods and assessment criteria is expected in the future research. The decontamination technology, especially the bioremediation technology, is still at a developing stage. It may become a "hot" topic in the field of environmental study to meet the needs of protecting environment and ecological system [99, $100]$.

\section{Compliance with Ethical Standards}

Conflict of Interest Yunfang Li, Lei Guo, and Huan Feng declare that they have no conflict of interest. 


\section{References}

1. Gao B, Lu J, Hao H, et al. Heavy metals pollution and $\mathrm{Pb}$ isotopic signatures in surface sediments collected from Bohai Bay, north China. Sci World J. 2014;2014, 158796. doi:10.1155/2014/ 158796. 6 pages.

2. Gao XL, Zhuo FX, Chen CTA. Pollution status of the Bohai Sea: an overview of the environmental quality assessment related trace metals. Environ Int. 2014;62:12-30.

3. Zhan Y. Contamination of heavy metal and its affection to the growing of typical phytoplankton in Bohai Sea [D]. Qingdao: the Ocean University of China; 2005 (In Chinese).

4. Zhang L, Qin Y, Binghui Z, et al. Distribution and pollution assessment of heavy metals in sediments from typical are as in the Bohai Sea [J]. Acta Sci Circumst. 2011;31(8):1676-83 (In Chinese).

5. National Bureau of Environmental Protection. Study on pollution prevention and control in Bohai and the yellow Sea area [M], vol. 56. Beijing: Science Press; 1990. p. 221-9.

6. Li SY, Miao FM, Liu GX, et al. The preliminary research on environment background concentrations of heavy metal in sediment of the Bohai Sea[J]. Acta Oceanol Sin. 1995;17:78-85 (In Chinese).

7. Cheng L, Zhaoyin W, He Y, et al. Evaluation on the potential ecological risk for the river mouths around Bohai Bay [J]. Research of Environmental Sciences. 2002;15(5):33-7.

8. Qian W, Shi J, Chen J, et al. Contents, Distributions, Forms and Inter-facial Process of Heavy Metal in Jinzhou Bay [A]. Beijing: Chinese Environment Science Press; 1992. p. 171-88 (In Chinese).

9. Jianglin C, Wenxin L, Shuzhen L, et al. An evaluation on heavy metal contamination in the surface sediments in Bohai Sea [J]. J Mar Sci. 2004;28(12):16-21 (In Chinese).

10. $\mathrm{Xu} \mathrm{H}$, Chuanguang $\mathrm{Z}, \mathrm{Ma} \mathrm{Y}$, et al. Environmental quality of deposits in offshore zone of China [J]. Traffic Environ Prot. 2000;21(3):16-8. 46. (In Chinese).

11. Blue Bohai Sea Plan, The country letter. 2001;124.

12. Baudouin C, Charveron M, Tarroux R, et al. Environmental pollutants and skin cancer. Cell Biol Toxicol. 2002;18:341-8.

13. Graeme KA, Pollack Jr CV. Heavy metal toxicity.Part I:Arsenic and Mercury[J]. J Emerg Med. 1998;16:45-56.

14. Graeme KA, Pollack Jr CV. Heavy metal toxicity.Part II:lead and metal fume fever[J]. J Emerg Med. 1998;16:171-7.

15. Jingsheng C, Deng B, Tao S, et al. Environmental geochemistry [J]. Beijing: China Ocean Press; 1990. p. 196-235 (In Chinese).

16. Chen J. Principle of river water quality and river water quality in China [M]. Beijing: Science Press; 2006 (In Chinese).

17. Zhang Y, Shibao H, Jingjing D, et al. Advances in heavy metal research of river sediment [J]. Journal of Yunnan Agricultural University. 2009;24(4):630-3 (In Chinese).

18. Feng H, Jiang H, Gao W, Weinstein MP, Zhang Q, Zhang W, et al. Metal contamination in sediments of the western Bohai Bay and adjacent estuaries. China. J Environ Manag. 2011;92:1185-97.

19. Li S, Hao J. The study of environment background concentrations of $\mathrm{Cu}, \mathrm{Pb}, \mathrm{Zn}, \mathrm{Cd}$ in the Sediment of the Bohai Bay and adjacent Sea area[J]. Oceanologia ET Limnologia Sinica. 1992;23(1):3948.

20. Li S, Guoxian L, Fengmin M. The distribution and environmental background values of the heavy metal sediment of the Bohai Sea [J]. China Environ Sci. 1994;14(5):370-6 (In Chinese).

21. Cao H, Liang T, Wang L, et al. Contents and distribution of heavy metals in water and sediment of intertidalite. J Environ Sci. 2006;27(1):126-31 (In Chinese).

22. Reddy MS, Basha S, Kumar VGS, et al. Distribution, enrichment and accumulate of heavy metals in costal sediments of Alang-
Sosiya ship scrappingyard, India[J]. Mar Pollut Bull. 2004;48(11):1055-9.

23. $\mathrm{Hu} \mathrm{N}$, Xuefa S, Peng H, et al. Distribution of metals in surface sediments of Liaodong Bay, (In Chinese). Bohai Sea [J]. China Environ Sci. 2010;30(3):380-8.

24. Hu B, Li GG, Li J, Bi JQ, Zhao JT, Bu RY. Spatial distribution and ecotoxicological risk assessment of heavy metals in surface sediments of the southern Bohai Bay, China. Environ Sci Pollut Res. 2013;20:4099-110.

25. Hu B, Li J, Zhao JT, Yang J, Bai FL, Dou YG. Heavy metal in surface sediments of the Liaodong Bay, Bohai Sea: distribution, contamination, and sources. Environ Monit Assess. 2013;185: 5071-83.

26. Zhou X, Yubin L, Wang E, et al. Pollution and risk assessment of heavy metals in Liaodong Bay Wetland [J]. Environ Sci Technol. 2004;27(5):60-2 (In Chinese).

27. Li R, Li Y. Environmental and sedimentological survey along the coast of Bohai gulf [J]. Acta Sedimentol Sin. 2008;26(1):128-38 (In Chinese)

28. Liu B, Hu K, Jiang Z, Fengge Q, Xin S. A 50-year sedimentary record of heavy metals and their chemical speciations in the Shuangtaizi River estuary (China): implications for pollution and biodegradation. Front Environ Sci Eng China. 2011;5(3):435-44.

29. Zhang Y, Wang L, Chuanlin H, et al. Pollution evaluation on heavy metals in surface sediments in Jinzhou Bay [J]. Mar Environ Sci. 2008;27(3):258-60 (In Chinese).

30. Li Z, Herong D, Linhua S. Research progress on source analysis of heavy metal in river sediments $[\mathrm{J}]$. Chemical Analysis and Meterage. 2012;21(5):94-6 (In Chinese).

31. Luo W, Lu Y, Wang T. Ecological risk assessment of arsenic and metals in sediments of coastal areas of northern Bohai and Yellow Seas, China. Ambio. 2010;39:367-75.

32. Luo W, Lu YL, Wang TY, Kong PR, Jiao WT, Hu WY, et al. Environmental concentrations and bioaccumulations of cadmium and zinc in coastal watersheds along the Chinese Northern Bohai and Yellow Seas. Environ Toxicol Chem. 2013;32(4):831-40.

33. Gao XL, Chen CTA. Heavy metal pollution status in surface sediments of the coastal Bohai Bay. Water Res. 2012;46:1901-11.

34. Gao XL, Yang YW, Wang CY. Geochemistry of organic carbon and nitrogen in surface sediments of coastal Bohai Bay inferred from their ratios and stable isotopic signatures. Mar Pollut Bull. 2012;64:1148-55.

35. Guo WH, Liu XB, Liu ZG, Li GF. Pollution and potential ecological risk evaluation of heavy metals in the sediments around Dongjiang Harbor, Tianjin. Procedia Environ Sci. 2010;2:729-36.

36. Wu GH, Shan Shan C, Shui Rong C, Fang Ting C. Accumulation and remobilization of metals in superficial sediments in Tianjin, China. Environ Monit Assess. 2011;173:917-28.

37. Wua G, Shang J, Pan L, Wanga Z. Heavy metals in surface sediments from nine estuaries along the coast of Bohai Bay, Northern China. Mar Pollut Bull. 2014;82:194-200.

38. Zhou R, Qin X, Peng S, Deng S. Total petroleum hydrocarbons and heavy metals in the surface sediments of Bohai Bay, China: long-term variations in pollution status and adverse biological risk. Mar Pollut Bull. 2014;83:290-7.

39. Meng W, Shengjia Z, Yanwen Q, et al. Sources identification of heavy metals in core sediments of Bohai Bay [J]. Mar Sci Bull. 2006;25(2):62-9 (In Chinese).

40. Qin Y, Yibing S, Zheng B, et al. Heavy metals and pollution assessment in surface sediments of Bohai Bay [J]. J Mar Sci. 2007;31(12):28-33 (In Chinese).

41. Zhang F, Baixing Y, Zhu L. Speciation of heavy metals in sediment of the Songhua river [J]. J Argo-Environ Sci. 2010;29(1): 163-7 (In Chinese).

42. Zhang $\mathrm{X}$, Ding $\mathrm{D}, \mathrm{Xu}$ J, et al. Heavy metal in Sea water and sediment investigation at Bohai Sea western estuary tidal zone 
[J]. Journey of East China Institute of Technology. 2010;33(3): 276-80 (In Chinese).

43. Zhang D, Zheng X, He Y, et al. Pollution and risk assessment of heavy metals in surface sediment of south Bohai[J]. Prev Control Environ Pollut. 2011;33(9):8-10. 24. (In Chinese).

44. Zhan S, Shitao P, Chunguang L. Spatial and temporal variations of heavy metals in surface sediments in Bohai Bay, north China [J]. Bull Environ Contam Toxicol. 2010;84:482-7.

45. Qin Y, Wei M, Zheng B, et al. Contaminative features of heavy metals for tidal sediment cores in Tianjin Bohai Bay [J]. Environ Sci. 2006;27(2):268-73 (In Chinese).

46. Meng W, Yanwen Q, Zheng B, et al. Heavy metal pollution in Tianjin Bohai Bay, China [J]. J Environ Sci. 2008;20(7):814-9.

47. Gao XL, Li PM. Concentration and fractionation of trace metals in surface sediments of intertidal Bohai Bay, China. Mar Pollut Bull. 2012;64:1529-36.

48. Zhang MQ, Chen SR, Wu GH, et al. Characteristics of heavy metal pollution in surficial sediment of Dagu estuary in Bohai Bay[J]. Environmental Science and Management. 2012;36(12): 42-7 (In Chinese).

49. Luo W, Wang T, Jiao WT, Hu WY, Naile JE, Khim JS, et al. Mercury in coastal watersheds along the Chinese Northern Bohai and Yellow Seas. J Hazard Mater. 2012;215:199-207.

50. Luo W, Lu YL, Wang TY, Kong PR, Jiao WT, Hu WY, et al. Environmental concentrations and bioaccumulations of cadmium and zinc in coastal watersheds along the Chinese Northern Bohai and Yellow Seas. Environ Toxicol Chem. 2013;32(4):831-40.

51. Hu N, Jihua L, Peng H, et al. The distribution and risk assessment of metals in surface sediments of the Laizhou Bay in the Bohai Sea [J]. Acta Oceanol Sin. 2012;34(2):92-100 (In Chinese).

52. Wu XY, Liu RH, Qin J, Sun PY, Gao ZW, Jia YG. Study on the variance character of heavy metals contents in sediments in Yellow River Estuary. Trans Oceanol Limnol. 2007;69-74. [In Chinese with English abstract].

53. $\mathrm{Hu} \mathrm{B}, \mathrm{Li} \mathrm{G}, \mathrm{Li} \mathrm{J}$, et al. Spatial variability of the sedimentation rates in the Bohai and yellow seas and its influencing factors [J]. Acta Oceanol Sin. 2011;33(6):125-33.

54. Hu NJ, Shi XF, Liu JH, Huang P, Yang G, Liu YG. Distributions and impacts of heavy metals in the surface sediments of the Laizhou Bay. Adv Mar Sci. 2011;29:63-71 (In Chinese).

55. Liu M, Aibin Z, Dejiang F, et al. Environmental quality of heavy metals in surface sediments in the central region of the Bohai Sea [J]. China Environ Sci. 2012;32(2):279-90 (In Chinese).

56. Li R, He L, Yuan L, et al. Study of the heavy metals, nitrogen and phosphorus contaminants in the sediments of the yellow river Delts [J]. Acta Sedimentol Sin. 2001;19(4):622-9 (In Chinese).

57. Gao XL, Zhuang W, Chen CTA. Sediment Quality of the SW Coastal Laizhou Bay, Bohai Sea, China: Assessment Based on the Analysis of Heavy Metals. Sediment Quality and Heavy Metal. 2015;1-28.

58. Qin Y, Wei M, Zheng B, et al. Heavy metal pollution in tidal zones of Bohai Bay using the dated sediment cores [J]. J Environ Sci. 2006;18(3):610-5.

59. Liu C, Wang Z, Heyun, et al. Investigation on sedimnet quality of the river mouths around Bohai Bay [J]. Acta Sci Circumst. 2003;23(1):58-63 (In Chinese).

60. Mao T, Mingxin D, Shitao P, et al. Temporal-spatial variation trend analysis of heavy metals $(\mathrm{Cu}, \mathrm{Zn}, \mathrm{Pb}, \mathrm{Cd}, \mathrm{Hg})$ in Bohai Bay in 10 years [J]. Journal of Tianjin University. 2009;42(9):817-25 (In Chinese).

61. Zhang Y, Lu X, Honglei L, et al. Distribution characteristics and source identification of heavy metals in surface sediments of Bohai Bay near Tianjin[J]. Research of Environmental Sciences. 2014;27(6):608-14 (In Chinese).
62. Qi F, Zheng B, Wan J, et al. Pollution of heavy metal in the sample of column of Bohai Bay in Tianji $[\mathrm{J}]$. J Ocean Technol. 2004;23(3):85-91 (In Chinese).

63. Xu Y, Jinming S, Xuegang L, et al. Geochemical characteristics of heavy metals in different fraction and their environmental significance in Bohai Bay sediment cores China [J]. J Agro-Environ Sci. 2011;30(12):2560-70 (In Chinese).

64. Xu B, Zhaoyan G, Jingtai $\mathrm{H}$, et al. Sequential exactractions and isotope analysis for discriminating the chemical forms and origins of $\mathrm{Pb}$ in sediment from Liaodong Bay, China. Arch Environ Contam Toxicol. 2009;57:230-8.

65. Xu B, Yang X, Zhaoyan G, et al. The tread and extend of heavy metal accumulation over last one hundred years in the Liaodong Bay, China. Chemosphere. 2009;75:442-6.

66. CSBTS (China State Bureau of Quality and Technical Supervision). The People's Republic of China National Standards GB 18668-2002 - Marine Sediment Quality. 2002; $10 \mathrm{pp}$ (in Chinese).

67. Zhu G, Yingxu C, Gendi Z, et al. Distribution of heavy metals in the sediments from the grand canal (Hangzhou section) [J]. China Environ Sci. 2011;21(1):65-9 (In Chinese).

68. Goldberg ED, Koide M. In: Geiss J, Goldberg ED, editors. Earth science and meteoritics [C]. Amsterdam: North-Holland Publishing Company; 1963. p. 90-102.

69. Qi J, Li FY, Song JM. Distribution of activity of sediments in the yellow and Bohai seas [J]. PbGeochimica. 2005;34(4):351-6 (In Chinese).

70. Meng W, Lei K, Zheng BH. Modern sedimentation rates in the intertidal zone on the west coast of the Bohai gulf [J]. Acta Oceanol Sin. 2005;24(3):46-53.

71. Feng H, Weiguo Z, Li J, et al. Short- and long-term sediment transport in western Bohai Bay and coastal areas[J]. Chin J Oceanol Limnol. 2010;28(3):583-92.

72. Presley BJ, Taylor RJ, Boothe PN. Trace metal concentrations in sediments of eastern Mississippi bight [J]. Mar Environ Res. 1992;33:267-82.

73. Tkalin AV, Presley BJ, Boothe PN. Spatial and temporal variations of the metals in bottom sediments of peter the great Bay, the Sea of Japan [J]. Environ Pollut. 1996;92:73-8.

74. Govelli S, Fontolau G. Application of a normalization procedure in determining regional geochemical baselines [J]. Environ Geol. 1997;30(1-2):34-5.

75. Hirst DM. The geochemistry of modern sediments from the gulf of Paria [J]. Geochim Cosmochim Acta. 1962;26: 1147-87.

76. Summer JK, Wade TL, Engle VD, et al. Normalization of metal concentration in estuarine sediments from the gulf of Mexico [J]. Estuaries. 1996;19:581-94.

77. Chen JL, Liu WX, Liu SZ, et al. An evaluation on heavy metal contamination in the surface sediments in Bohai Sea [J]. J Mar Sci. 2004;28(12):16-21.

78. Windom HL, Slipipot S, Chanpongsang A, et al. Trace metal composition and accumulation rates of sediments in the upper gulf of Thailand[J]. Estuar Coast Shelf Sci. 1984;19:133-42.

79. Liu S, Jing Z. Normalization of heavy metals to aluminum in marine sediments [J]. Donghai Marine Sience. 1998;16(3):48-55 (In Chinese)

80. Zhao Y, Yan M. Shallow sea sediment geochemistry in China [M] Beijing: Science Press; 1994. p. 181-2 (In Chinese).

81. Gibbs RJ. Metals in the sediment along the Hudson river estuary. Environ Int. 1994;20:507-16.

82. Liu E, Shen J, Zhu Y, et al. Source analysis of heavy metals in surface sediments of Lake Taihu [J]. J Lake Sci. 2004;16(2):113-9 (In Chinese). 
83. Trefry JH, Sadoughi M, Sullivan MD, et al. Trace metals in the India river lagoon, Florida: the copper story [J]. Florida Scientist. 1983;46:415-27.

84. Xu Y, Jinming S, Xuegang L, et al. Variation characteristics and potential ecology risk assessment of heavy metals in the surface sediments of Bohai Bay [J]. Environmental Science. 2012;33(3): 733-40 (In Chinese).

85. Hakanson L. An ecological risk index for aquatic pollution contral: a sedimentological approach [J]. Water Res. 1980;14: 975-1001.

86. Peng S, Hu Y, Zhipeng B. Pollution assessment and ecological risk evaluation for heavy metals in the sediments of Bohai Bay [J]. J Waterw Harb Coast Eng Div. 2009;30(1):57-60 (In Chinese).

87. Wang L, Jingsheng C, Huamin L. Research on deriving sediment quality criteria for heavy metals using the biological effect database approach-as Jinzhou gulf, Bohai Sea an example [J]. Acta Sci Nat Univ NeiMongol. 2004;34(4):467-72 (In Chinese).

88. Zhou B, Wei L, Yougang L, et al. Potential ecological risk analysis of heavy metals in the surface sediments from typical ecologically regions of South Bohai Bay [J]. Mar Environ Sci. 2013;32(4): 533-7 (In Chinese).

89. Muller G. Index of geoaccumulation in sediments of the Rhinc river [J]. GeoJournal. 1969;2(3):108-18.

90. Luo X, Rui Z, Yang J, et al. Distribution and pollution assessment of heavy metals in surface sediment in Laizhou Bay [J]. J Ecol Environ Sci. 2010;19(2):262-9 (In Chinese).

91. Ingersoll CG, Haverland PS, Brunson EL. Calculation and evaluation of sediment effect concentrations for the amphipod hyalella azteca and the midge Chironomus riparius. J Great Lakes Res. 1996;22:602-23.

92. Long ER, Morgan LG. The potential for biological effects of sediment-sorbed contaminants tested in the National Status and
Trends Program. NOAA Technical Memorandum NOS OMA 52. Seattle, Washington: National Oceanic and Atmospheric Administration; 1990. 175 pp.

93. Long ER, Macdonald DD, Smith SL, Calder FD. Incidence of adverse biological effects within ranges of chemical concentrations in marine and estuarine sediments. Environ Manag. 1995;19:81-97.

94. Long ER, Field LJ, MacDonald DD. Predicting toxicity in marine sediments with numerical sediment quality guidelines. Environ Toxicol Chem. 1998;17:714-27.

95. Urban DL, Cook NJ. Hazard evaluation, standard evaluation procedure, ecological risk assessment. Washington: Environmental Protection Agency; 1986. EPA540-9-85-001.

96. Finger SE, Farag AM, Nimick DA, Church SE, Sole TC. Synthesis of water, sediment, and biological data using hazard quotients to assess ecosystem health, chap. C. In: Nimick DA, Church SE, Finger SE, editors. Integrated investigations of environmental effects of historical mining in the basin and boulder mining districts, boulder river watershed, Jefferson county, vol. 1652. Montana. U.S: Geological Survey Professional Paper; 2004. p. 29-48.

97. Wang XL, Tao S, Dawson RW, Xu FL. Characterizing and comparing risks of polycyclic aromatic hydrocarbons in a Tianjin wastewater-irrigated area. Environ Res. 2002;90:201-6.

98. Jiang Bingyan, Wang Linlin. Research Status and Progress of Heavy Metal Pollution in Sediments of River System in China [J]. Sci Tech Inf Process, 2009 (9): 383, 374. (In Chinese)

99. Zhu Y, Jiahu J. Research status and progress of heavy metal pollution in sediments of Lake Wetland [J]. Journal of Anhui Agri Sci. 2010;38(22):11902-5. 11928.

100. Zhai Y, Sen G. Research advance in heavy metals in stream sediment [J]. Acta Agric Jiangxi. 2009;21(1):127-30 (In Chinese). 